\title{
METHODS APPLIED FOR MEASUREMENT AND VISUALIZATION OF CHANGES IN BIODIVERSITY
}

\author{
METODY POMIARU I WIZUALIZACJI ZMIAN BIORÓŻNORODNOŚCI
}

\begin{abstract}
The article presents the possible methods for determining biological or statistically significant differences between taxocenoses compared with respect to biodiversity. To obtain a complete description of biological differences between the compared hypothetical communities, the following indices were calculated: $S$ (taxon richness), $H^{\prime}$ (the Shannon index), $H_{\max }$ (the maximum value of the Shannon index for the richness of taxa represented by the same number of individuals), $V_{d}$ (a percentage value of covering the structural capacity of community, "evenness deficiency"), $E$ (the MacArthur index - a taxon number $(S)$ in a community for which the observed value of $H$ equals $H_{\max }$ ), and $P_{s}$ (a taxon richness shortage in percents). Moreover, a graphic profile method ( $\Delta_{\beta}, T_{j}$, and $L_{j}$ profiles) was used for comparing the diversity of the communities. To obtain information about statistically significant differences in biodiversity between the analysed communities, rarefaction curves were applied. The curves are based on the null models and the Monte Carlo method. The rarefaction method resulted in determination of the statistical significance of the differences between taxon richness and Shannon's index values for the compared communities. The $V_{d}$ and $P_{s}$ indices and the profile method allowed concluding about the significance of the biological differences between taxocenoses, even when their values of Shannon's $H$ ' indices were numerically similar.
\end{abstract}

Keywords: biodiversity, Shannon's index, rarefaction curves, profile method

\section{Introduction}

While undertaking the 'strategy of protection and rational use of biological diversity' $[1,2]$, as well as biomonitoring processes in bioreactors with activated sludge [3-7] and surface water eg [8-12], an ideal solution would be creating conditions that would ensure 'control of strategy to be realized', where the monitoring, ie systematic measurements, would be carried out and the measurement results could be reliably compared. Biodiversity (biological diversity $\alpha, \beta$, and $\gamma$ ) may be evaluated based on the richness of species $S$ or taxa selected at own preference [13]. It may also be assessed in terms of the number of taxa and their relative abundance (or relative biomass, or relative coverage degree) by calculating

\footnotetext{
${ }^{1}$ Faculty of Environmental Engineering, Lublin University of Technology, ul. Nadbystrzycka 40B, 20-618 Lublin, Poland, phone +48 815384322

${ }^{2}$ Faculty of Civil Engineering, Czech Technical University in Prague, Thakurova 7, 16629 Prague, Czech Republic, phone +42022435 5412, email: stransky@ fsv.cvut.cz

*Corresponding author: g.lagod@pollub.pl
} 
Shannon's index of diversity $H^{\prime}$ [14-17], or other biotic indices [18-23]. While applying methods for description of communities based on $S$ or $H^{\prime}$ indices, it is not possible to assess correctly the biological or statistically significant differences (or absence of such differences) between compared taxocenoses characterised by identical or subjectively different $S$ and $H^{\prime}$ values. Nowadays, there are means to solve this problem [24-28]. It seems that these methods are not yet widely used in the field of environmental engineering. Hence, the objective of the present paper is to show them using a simple example of three hypothetical communities of living organisms.

\section{Materials and methods}

The material used in the investigations comprised three hypothetical communities, two of which had the same $S$ values (species richness), but differed with respect to the $H^{\prime}$ values (Shannon's index). Two exhibited similar $H^{\prime}$ values, but differed in the $S$ values; the problem is better illustrated by the fact that they had the same number of individuals $N=20$ (Table 1).

Table 1

Taxonomic-biocenotic characteristics of three hypothetical communities A, B, and C

\begin{tabular}{|c|c|c|c|}
\hline \multirow{2}{*}{ Taxa } & \multicolumn{3}{|c|}{ Community } \\
\cline { 2 - 4 } & $\mathbf{A}$ & $\mathbf{B}$ & $\mathbf{C}$ \\
\hline$s_{i}$ & $n_{i}$ & $n_{i}$ & $n_{i}$ \\
\hline $\mathrm{A}$ & 4 & 10 & 6 \\
\hline $\mathrm{B}$ & 4 & 1 & - \\
\hline $\mathrm{C}$ & 4 & 3 & 4 \\
\hline $\mathrm{D}$ & 4 & 2 & 7 \\
\hline $\mathrm{E}$ & 4 & 4 & \\
\hline
\end{tabular}

The formulas presented below were used in measurements and comparisons of the biological diversity of the communities (objects) characterised [27, 29-34].

The species richness $S$ was established by simply summing all of the taxa belonging to the analysed community and the same method was used for $N$ [32]:

$$
\begin{gathered}
S=\sum_{i=1}^{s} s_{i} \\
N=\sum_{i=1}^{S} n_{i}
\end{gathered}
$$

where: $S$ - species richness, number of taxa; $s_{i}$ - distinguished taxon; $N$ - total number of individuals in the sample (total number of individuals in taxocenosis); $n_{i}$ - number of individuals of the $i^{\text {th }}$ taxon.

Relative abundances, necessary for calculation of the Shannon index and derived indices, were determined on the basis of the following equation [32]:

$$
\Pi_{i}=\frac{n_{i}}{N}
$$

where $\Pi_{i}$ - relative abundance of the $i^{\text {th }}$ taxon. 
The $H^{\prime}$ Shannon index was calculated on the basis of the following equation $[32,33]$ :

$$
H^{\prime}=-\sum_{i=1}^{S} \Pi_{i} \lg _{2} \Pi_{i}
$$

where $H^{\prime}$ - Shannon's index of biodiversity.

The maximum value of the Shannon index $H^{\prime}{ }_{\max }[30,31]$ was calculated using the following formula:

$$
H^{\prime}{ }_{\max }=\lg _{2} S
$$

where $H^{\prime}{ }_{\max }$ - maximum $H^{\prime}$ value for a given richness $S$, which would occur if all taxa were equally abundant.

The evenness deficiency index $V_{d}$ was calculated based on the concept presented by Hurlbert and Magurran [30, 31]:

$$
V_{d}=\left(1-\frac{H^{\prime}}{H_{\max }^{\prime}}\right) \cdot 100
$$

where $V_{d}$ - a percentage value of implementation of community capacity (evenness deficiency).

MacArthur's index $E$ was calculated according to the following equation [29]:

$$
E=2^{H^{\prime}}
$$

where $E$ - species richness of a community, for which the observed $H^{\prime}$ is the $H^{\prime}{ }_{\max }$ value.

The proportionality shortage index $P_{s}$ was calculated based on the concept presented in [27]:

$$
P_{s}=\left(1-\frac{E}{S}\right) \cdot 100
$$

where $P_{s}$ - expressed in percent species shortage.

Additionally, a graphic profile method of $\Delta_{\beta}, T_{j}$, and $L_{j}$ was applied to compare the biodiversity of the communities [32]. The $\Delta_{\beta}$ profiles were plotted on the basis of the points on the coordinate axes $\left(\beta, \Delta_{\beta}\right)$, where $\beta>-1$ and $\Delta_{\beta}$ can be described by the following formula $[35,36]$ :

$$
\Delta_{\beta}=\sum_{i=1}^{S}\left\{\frac{1-\Pi_{i}^{\beta}}{\beta}\right\} \Pi_{i}=\frac{1-\sum_{i=1}^{S} \Pi_{i}^{\beta+1}}{\beta}
$$

The $T_{j}$ profiles were plotted on the basis of the points on the coordinate axes $\left(j, T_{j}\right)$, where $j=1, \ldots, S-1, S$, and $T_{j}$ is described by the following formula [35, 37]:

$$
T_{j}=\sum_{i=j+1}^{S} \Pi_{i}^{\#}\left(\text { for } j=S, T_{S}=0 ; \text { for } j=0, T_{0}=1\right)
$$

where: $\Pi_{i}^{\#}$ - relative abundance of the $i^{\text {th }}$ species, classified into the so-called ranked relative abundance vector $\left(\Pi^{\#}\right)$, which covers the relative abundances of all species ordered from the greatest to the lowest.

The latter profiles mentioned above, ie the $L_{j}$ profiles, were plotted on the basis of the points on the coordinate axes $\left(L, L^{\prime}\right)$. Calculations of the coordinates were performed based 
on ranked relative abundance vectors $\Pi^{\#}, \Pi^{\# \prime}$ of the compared communities, as follows [38]:

$$
\begin{gathered}
p_{0}=\left(L_{0}, L_{0}^{\prime}\right)=(0,0) \\
p_{1}=\left(L_{1}, L_{1}\right)=\left(\Pi_{1}^{\#}, \Pi_{1}^{\#{ }^{\prime \prime}}\right) \\
p_{2}=\left(L_{2}, L_{2}^{\prime}\right)=\left(L_{1}+\Pi_{2}{ }^{\#}, L^{\prime}{ }_{1}+\Pi_{2}{ }^{\# \prime}\right) \\
\cdot \\
\cdot \\
\cdot \\
p_{k}=\left(L_{k}, L^{\prime}{ }_{k}\right)=\left(L_{k-1}+\Pi_{\mathrm{k}}^{\#}, L^{\prime}{ }_{k-1}+\Pi_{k}^{\#{ }^{\prime}}\right) \\
p_{s}=\left(L_{s}, L_{s}^{\prime}\right)=\left(L_{s-1}+\prod_{\mathrm{s}}^{\#}, L_{s-1}+\Pi_{s}^{\# \prime^{\prime}}\right)=(1,1)
\end{gathered}
$$

Null models were applied to obtain information about the statistically significant differences between the communities analysed in terms of the taxa richness and diversity. These models (based on the Monte Carlo method) enable statistical significance to be determined even if the sizes of compared samples are not the same $-N_{1} \neq N_{2}[25,26]$. Eco Sim 7.0 software [24-26] was used for calculations concerning the analysed communities $\mathrm{A}, \mathrm{B}$, and $\mathrm{C}$, and data required for plotting rarefaction curves.

\section{Results and discussion}

Table 2 shows the results of calculations made according to formulas (1)-(4).

Taxa richness, total abundance, and Shannon's index for communities A, B, and C

\begin{tabular}{|c|c|c|c|}
\hline \multirow{2}{*}{ Index } & \multicolumn{3}{|c|}{ Community } \\
\cline { 2 - 4 } & $\mathbf{A}$ & $\mathbf{B}$ & $\mathbf{C}$ \\
\hline$S$ & 5 & 5 & 4 \\
\hline$N$ & 20 & 20 & 20 \\
\hline$H^{\prime}$ & 2.322 & 1.923 & 1.926 \\
\hline
\end{tabular}

Given the results presented above, it is hardly possible to state explicitly whether the communities compared, especially $\mathrm{B}$ and $\mathrm{C}$, vary with respect to the biological differences. However, the data presented in Table 3 allow a presumption that, in the biological sense, community $\mathrm{C}$ is characterised by lower biodiversity than community $\mathrm{A}$, but greater biodiversity than community $\mathrm{B}$, as it exhibits a lower evenness deficiency $V_{d}$ and a lower species shortage $P_{s}$. This is displayed by the AMOEBA-type graphs [39-42] - Figures 1 and 2.

Values of $H^{\prime}{ }_{\max }, V_{d}, E$, and $P_{s}$ indices for communities A, B, and C

\begin{tabular}{|c|c|c|c|}
\hline \multirow{2}{*}{ Index } & \multicolumn{3}{|c|}{ Community } \\
\cline { 2 - 4 } & $\mathbf{A}$ & $\mathbf{B}$ & $\mathbf{C}$ \\
\hline$H_{\max }^{\prime}$ & 2.323 & 2.323 & 2.0 \\
\hline$V_{d}$ & $0.0 \%$ & $17.2 \%$ & $3.7 \%$ \\
\hline$E$ & 5.0 & 3.793 & 3.800 \\
\hline$P_{s}$ & $0.0 \%$ & $24.2 \%$ & $5 \%$ \\
\hline
\end{tabular}



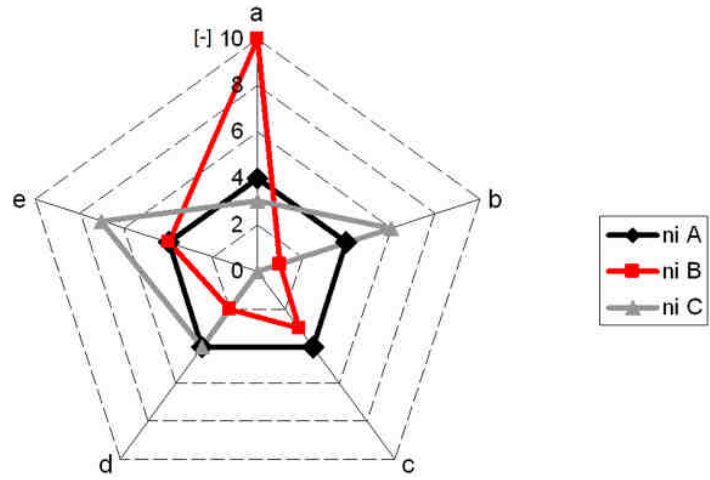

Fig. 1. Species richness $S$ of communities A, B, and C

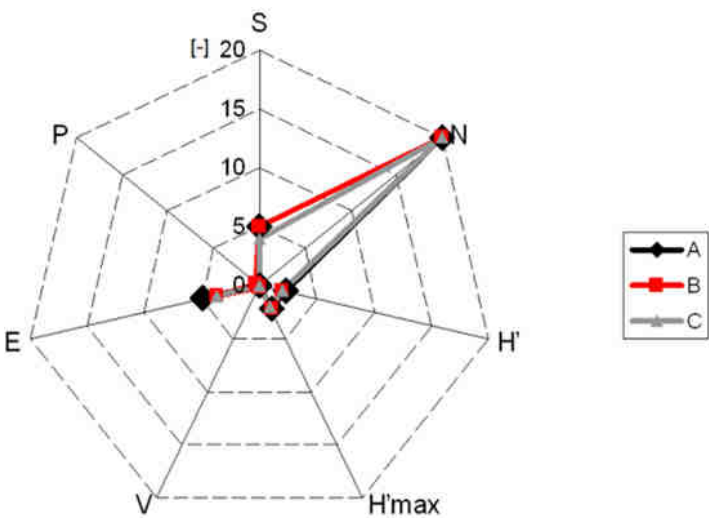

Fig. 2. Values of $H^{\prime}, S$ indices and derived indices for communities A, B, and C

Figures 3-7 show the results obtained with the profile method. It should be explained that the $\Delta_{\beta}$ profiles plotted for the compared communities show their ranking according to three indices: 'species count' $\Delta_{S i}=S-1$, Shannon's index and Simpson's index $\Delta_{S i}=1-\sum_{i=1}^{s} \Pi_{i}^{2}$. If these profiles do not cross each other, all the indices used rank the compared communities in the same way (ie according to all indices, a given community $\mathrm{X}$ is more diverse than $\mathrm{X}^{\prime}$ ). If the profiles cross, the ranks of the communities will depend on the index applied. The $T_{j}$ profiles have been developed based on the concept of intrinsic diversity ordering [36]. The mutual position of the $T_{j}$ profiles plotted for the compared communities allow conclusions concerning the intrinsic diversity ordering. If the profile of the $\mathrm{X}$ community lies above the profile of the $\mathrm{X}^{\prime}$ community, the $\mathrm{X}$ community is intrinsically more diverse, whereas the $X^{\prime}$ community is less diverse. When the profiles intersect, it is impossible to determine which of the communities compared is more intrinsically diverse. The $\Delta_{\beta}$ profiles are isotonic to $T_{j}$ profiles, which means that $\Delta_{\beta}$ profiles can inform about the intrinsic diversity ordering between the communities. It should be remembered, however, that sometimes the $\Delta_{\beta}$ profiles may not cross even if the $T_{j}$ profiles do. The $L_{j}$ profiles are curves, which are also based on the concept of intrinsic diversity 
ordering. While plotting these profiles, the points form curve $p$. Its position with respect to the diagonal $d$ (with the equation $y=x$ ) carries information concerning the intrinsic diversity ordering between the compared $\mathrm{X}$ and $\mathrm{X}$ ' communities. When the curve $p$ lies above the diagonal $d$, community $\mathrm{X}$ is intrinsically more diverse than $\mathrm{X}^{\prime}$. When the curve $p$ lies under the diagonal $d, \mathrm{X}^{\prime}$ is intrinsically more diverse than $\mathrm{X}$. If the curve $p$ and the diagonal $d$ overlap, there is no difference in the diversity between the communities. When the curve $p$ crosses the diagonal $d$, it is not possible to state which of the compared communities is more diverse. It should be noticed that the $T_{j}$ and $L_{j}$ profiles lead to the same conclusions. The selection of the type of the profile has no effect on the final result [32].

Based on the $\Delta_{\beta}$ profiles for the analysed communities, taxocenosis A can be regarded to be more diverse than taxocenoses $\mathrm{B}$ and $\mathrm{C}$, whereas taxocenoses $\mathrm{B}$ and $\mathrm{C}$ cannot be compared due to the crossing courses of the profiles (Fig. 3).

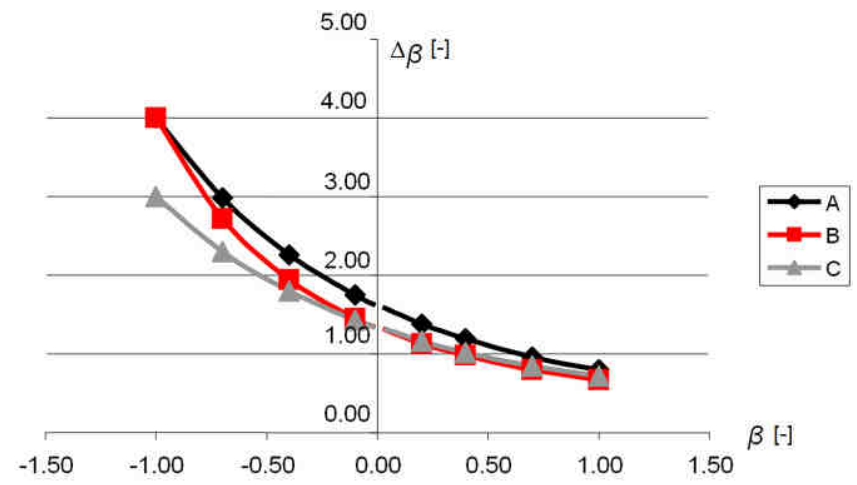

Fig. 3. The $\Delta_{\beta}$ profiles for communities $\mathrm{A}, \mathrm{B}$, and $\mathrm{C}$

The $T_{j}$ and $L_{j}$ profiles, similarly to the $\Delta_{\beta}$ profiles, indicate that community $\mathrm{A}$ is characterised by higher biodiversity than communities B and C (Figs. 4-6). Taxocenoses $\mathrm{B}$ and $\mathrm{C}$ are incomparable due to the crossing of the graphs of the respective $T_{j}$ and $L_{j}$ profiles (Figs. 4 and 7).

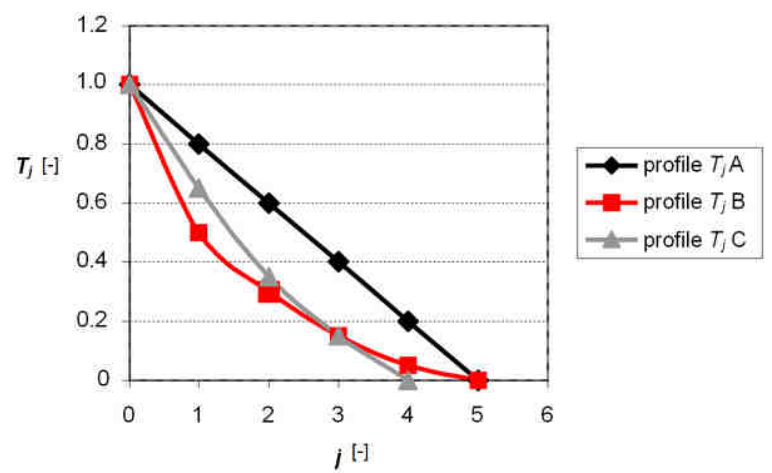

Fig. 4. The $T_{j}$ profiles for communities A, B, and C 

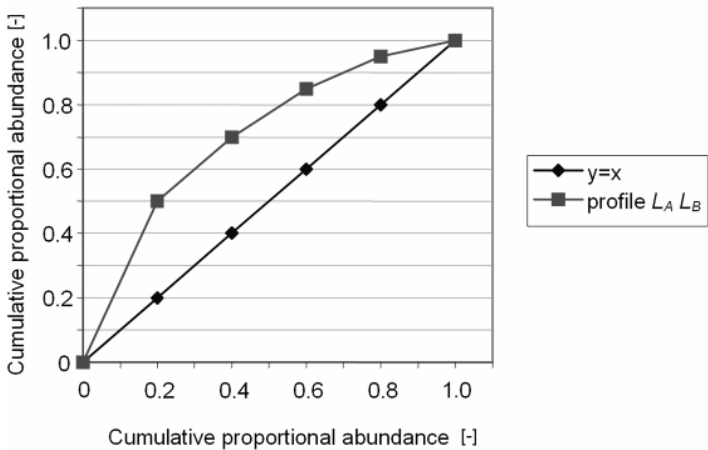

Cumulative proportional abundance $[-]$

Fig. 5. The $L_{j}$ profile for communities $\mathrm{A}$ and $\mathrm{B}$
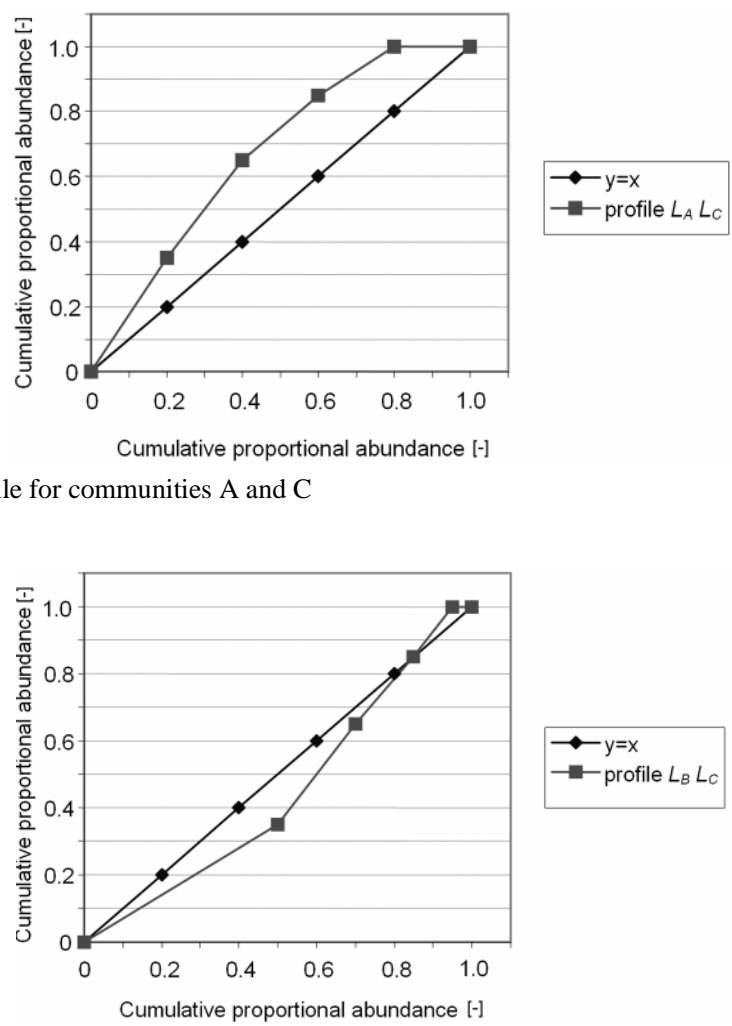

Fig. 7. The $L_{j}$ profile for communities B and C

The methods presented above do not yield judgements concerning the statistical significance of the differences or confidence intervals - the latter indicate the statistical significance of the differences if they do not overlap. Thus, it is not possible to decide about the significance of the differences between the communities compared. The problem discussed may be solved using multiple sampling methods. With these methods, rarefaction 
curves were obtained for the compared communities A, B, and C (Figs. 8 and 9). Figure 8 shows that multiple sampling of 4 individuals from 20 allows determination of the full number of species in community $\mathrm{C}$; only 5 individuals from 20 belonged to community A (in the upper graph the black dashed curve is comparable to red dashed curve). However, to get the full number of taxa in community B, multiple sampling of 10 individuals is required. A low number of taxa and individuals lead to certain 'angularity' of the graphs obtained; this should disappear in the case of more abundant samples $N>50$.

a)

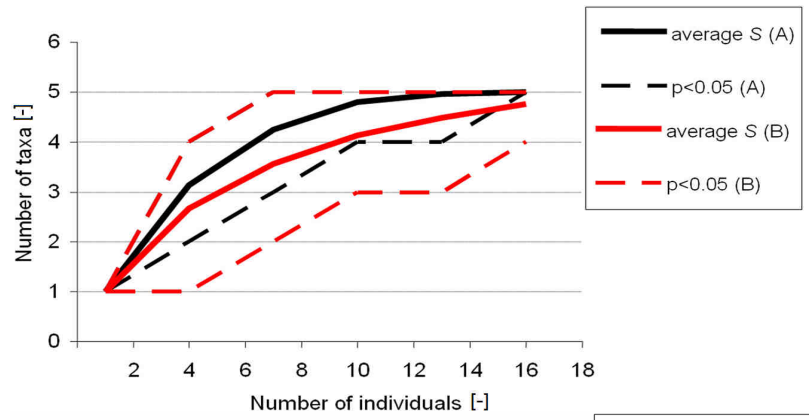

b)

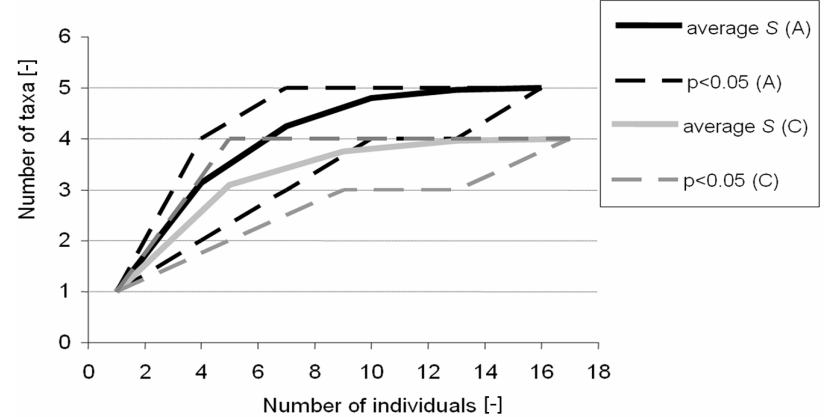

c)

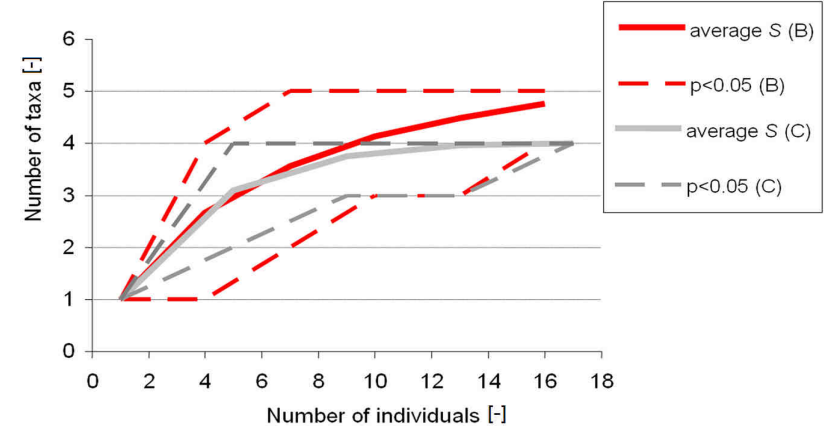

Fig. 8. Rarefaction curves of species richness for communities A, B, and C

The $H^{\prime}$ values calculated with the use of the EcoSim 7.0 software differ from those presented in Table 2. This can be explained by the fact that the EcoSim software calculates Shannon's index using a natural logarithm, while the base-2 logarithm is commonly applied in the theory of computer science. Hence, the $H^{\prime}(\mathrm{A})$ value is 1.61 , and $H^{\prime}(\mathrm{B})$ and $H^{\prime}(\mathrm{C})$ equal 1.33 . 
a)

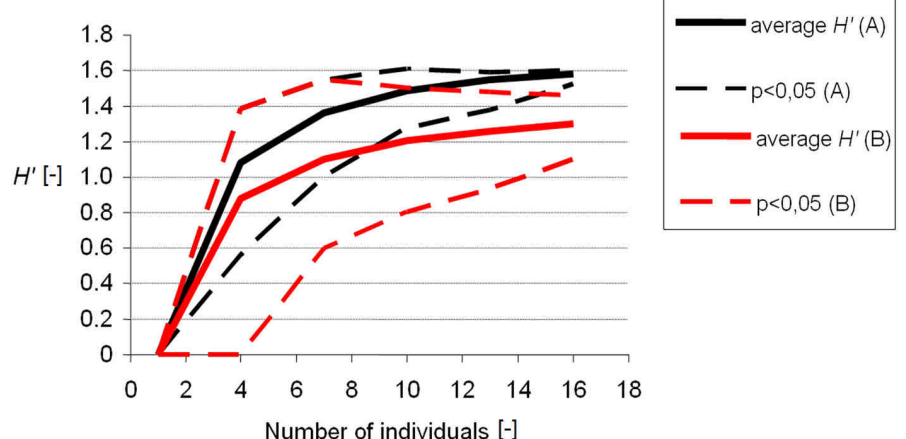

b)
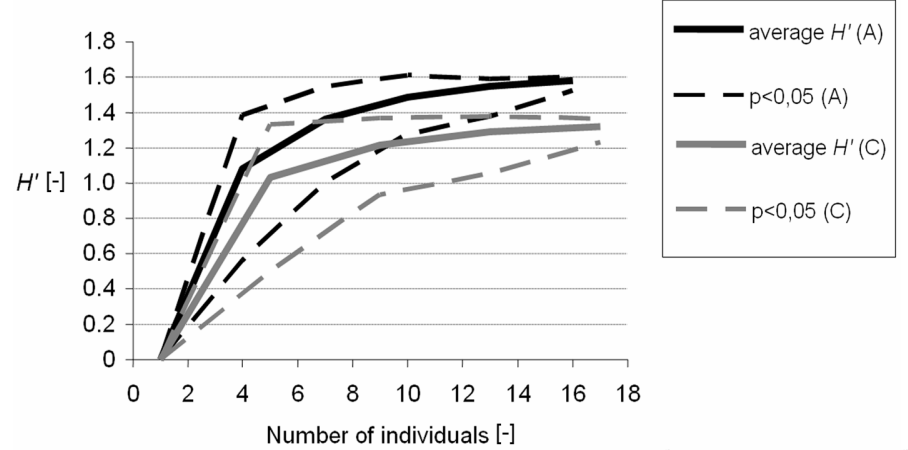

c)
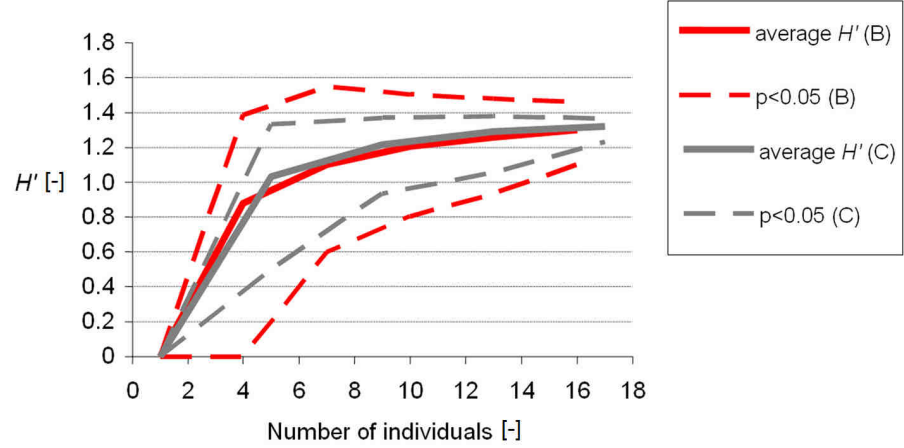

Fig. 9. Rarefaction curves of Shannon's index $H^{\prime}$ for communities A, B and C

Based on the results obtained, it may be presumed that in the case of Shannon's species diversity, taxocenosis A significantly differs from taxocenoses $\mathrm{B}$ and $\mathrm{C}$ (the confidence intervals do not overlap - Fig. 9a, b).Taxocenoses B and C do not differ in terms of the parameter discussed (the confidence intervals overlap - Fig. 9c).

The method of rarefaction presented in the article can be successfully applied not only for the number of taxa and Shannon's diversity index [24, 25, 28] but also for evaluation and analyses of other indices important in ecology. For instance, the effective number of species and, connected with this issue, problems of sample size, sample numbers, and sample coverage could be mentioned here [43]. 


\section{Conclusions}

The following conclusions can be drawn from the analysis of the results:

- It is possible to express biodiversity quantitatively, and after measurements thereof, taxocenoses and their changes in the time function can be compared with respect to this parameter.

- The indices developed, derivatives of the $H^{\prime}$ index (especially $V_{d}$ and $P_{s}$ ), indicate the significance of the biological differences, even when at similar values of the Shannon's $H^{\prime}$ indices.

- The $\Delta_{\beta}$ profiles serving the comparison of the values of species richness, Shannon's and Simpson's indices in the investigated taxocenoses, have a basic shortcoming - the $\beta$ values in the denominator of the fraction have to pass by 0 value, which is arithmetically inadmissible.

- The rarefaction methods facilitate determination of the statistical significance of the differences, or absence of the statistical differences, between Shannon's index values for the compared communities.

\section{Acknowledgements}

This work was supported partially by the Ministry of Science and Higher Education of Poland, Grant No.: 4949/B/T02/2008/34.

The work was presented at annual Central European Conference ECOpole.

\section{References}

[1] Directive 2000/60/EC of the European Parliament and of the Council of 23 October 2000 establishing a framework for Community action in the field of water policy.

[2] Andrzejewski R, Weigle A. Różnorodność biologiczna Polski (Biological diversity of Poland). Warszawa: Narodowy Fundusz Ochrony Środowiska; 2003.

[3] Curds CR. A theoretical study of factors influencing the microbial population dynamics of the activated sludge process - I The effects of diurnal variations of sewage and carnivorous ciliated protozoa. Water Res. 1973;7(9):1269-1284. DOI: 10.1016/0043-1354(73)90004-3.

[4] Al-Shahwani SM, Horan NJ. The use of protozoa to indicate changes in the performance of activated sludge plants. Water Res. 1991;25(6):633-638. DOI: 10.1016/0043-1354(91)90038-R

[5] Forney LJ, Liu WT, Guckert JB, Kumagai Y, Namkung E, Nishihara T, et al. Structure of microbial communities in activated sludge: Potential implications for assessing the biodegradability of chemicals. Ecotoxicol Environ Safety. 2001;49(1):40-53. DOI: 10.1006/eesa.2001.2034.

[6] De Gregorio C, Caravelli AH, Zaritzky NE. Application of biological indices and a mathematical model for the detection of metal coagulant overload in a laboratory scale activated sludge reactor with phosphate simultaneous precipitation. Chem Eng J. 2011;172(1):52-60. DOI: 10.1016/j.cej.2011.05.063.

[7] Babko R, Łagód G, Jaromin-Gleń KM. Abundance and structure of ciliated protozoa community at the particular devices of "Hajdów" WWTP. Ann Set Environ Protect. 2012;14:56-68.

[8] O'Reilly N, Novotny V. Water quality, ecological and flood risks to receiving waters due to urban runoff and urbanization. Technical report No. 2. Institute for Urban Environmental Risk Management, Marquette University; 1999.

[9] The Federal Interagency Stream Restoration Working Group (FISRWG) Stream Corridor Restoration Principles, Processes and Practices, by the Federal Interagency Stream Restoration Working Group, 1998.

[10] Ogbeibu AE, Orihabor BJ. Ecological impact of river impoundment using benthic macro-invertebrates as indicators. Water Res. 2002;36(10):2427-2436. DOI: 10.1016/S0043-1354(01)00489-4.

[11] Borchardt D, Richter S. Identification of significant pressures and impacts upon receiving waters. Water Sci Technol. 2003;48(10):33-38.

[12] Stastna G, Kabelkova I, Stransky D. Interaction of river dam and system sewer (in Czech). Stavebni obzor. 2008;17(1):16-20. 
[13] Whitaker RH. Evolutional measurements of species diversity. Taxon. 1972;21(2/3):213-251.

[14] Shannon CE, Weaver W. The Mathematical Theory of Communication. University of Illinois Press, Urbana, Chicago, 1949, reprint 1998.

[15] Woodiwiss FS. The biological system of stream classification used by Trent River Board. Chem Industry. 1964;11:443-447.

[16] Washington HG. Diversity, biotic and similarity indices: a review with special relevance to aquatic ecosystems. Water Res. 1984;18(6):653-694. DOI: 10.1016/0043-1354(84)90164-7.

[17] Brower JE, Zar JH, Von Ende CN. Field and Laboratory Methods for General Ecology. New York: WCB McGraw-Hill 1998.

[18] Madoni P. A sludge biotic index (SBI) for evaluation of activated sludge plants based on the microfauna analysis. Water Res. 1994;28(1):67-75. DOI: 10.1016/0043-1354(94)90120-1.

[19] Knoben RAE, Roos C, van Oirschot MCM. Biological assessment methods for watercourses. UN/ECE Task Force on Monitoring \& Assessment, Lelystad; 1995.

[20] Ravera O. A comparison between diversity, similarity and biotic indices applied to the macroinvertebrate community of a small stream: the Ravella river (Como Province, Northern Italy). Aquat Ecol. 2001;35:97-107.

[21] Gorzel M, Kornijów R. Biologiczne metody oceny jakości wód rzecznych. Kosmos. 2004;53(2):183-191.

[22] Kokes J, Zahradkova S, Nemejcova D, Hodovsky J, Jarkovsky J, Soldan T. The PERLA system in the Czech Republic: a multivariate approach for assessing the ecological status of running waters. Hydrobiologia. 2006;566(1):343-354. DOI: 10.1007/s10750-006-0085-4.

[23] Rożej A, Cydzik-Kwiatkowska A, Kowalska B, Kowalski D. Structure and microbial diversity of biofilms on different pipe materials of a model drinking water distribution systems. World J Microbiol Biotechnol. 2014:1-11. DOI: 10.1007/s11274-014-1761-6.

[24] Gotelli NJ, Entsminger GL. EcoSim: Null models software for ecology. Version 7.0, Jericho: Ackuiret Intelligence Inc. and Kesey-Bear, USA, 2006.

[25] Błędzki LA. Method for comparing species richness and species diversity (in Polish). Part I. Bioskop. 2007;1:18-22.

[26] Błędzki LA. Method for comparing species richness and species diversity (in Polish). Part II. Bioskop. 2007;2:20-23.

[27] Łagód G, Chomczyńska M, Montusiewicz A, Malicki J, Bieganowski A. Proposal of measurement and visualization methods for dominance structures in the saprobe communities. Ecol Chem Eng S. 2009;16(3):369-377.

[28] Colwell RK, Chao A, Gotelli NJ, Lin SY, Mao CX, Chazdon RL, et al. Models and estimators linking individual-based and sample-based rarefaction, extrapolation and comparison of assemblages. J Plant Ecol. 2012;5(1):3-21. DOI: 10.1093/jpe/rtr044.

[29] MacArthur RH. Patterns of species diversity. Biol Rev. 1965;40(4):510-533. DOI: 10.1111/j.1469-185X.1965.tb00815.x.

[30] Hulbert SH. The nonconcept of species diversity: a critique and alternative parameters. Ecology. 1971;52(4):577-586. DOI: 10.2307/1934145.

[31] Magurran A. Ecological Diversity and its Measurements. London, Sydney, Croom Helm; 1988.

[32] Gove IH, Patil GP, Swindel BF, Taille C. Ecological Diversity and Forest Management. Handbook of Statistic 12, Patil GP, Rao CR, editors. Amsterdam, London, New York, Tokyo: Elsevier Science; 1994;12:409-462. DOI: 10.1016/S0169-7161(05)80014-8.

[33] Krebs CJ. Ecology. The Experimental Analysis of Distribution and Abundance. Harper-Collins College Publishers; New York; 1994.

[34] Lamb EG, Bayne E, Holloway G, Schieck J, Boutin S, Herbers J, et al. Indices for monitoring biodiversity change: Are some more effective than others? Ecol Indicators. 2009;9(3):432-444. DOI: 10.1016/j.ecolind.2008.06.001.

[35] Patil GP, Taillie C. An overview of diversity. In: Ecological Diversity in Theory and Practice. Grassle JF, Patil GP, Smith W, Taillie C, editors. Fairland, MD: International Co-operative Publishing House; 1979: 23-48.

[36] Patil GP, Taillie C. Diversity as a concept and its measurement. J Amer Statist Assoc. 1982;77(379):548-567. DOI: 10.2307/2287709.

[37] Patil GP, Taillie C. A study of diversity profiles and orderings for a bird community in the vicinity of Colstrip, Montana. In: Patil GP, Rosenzweig ML, editors. Contemporary Quantitative Ecology and Related Econometrics. Fairland, MD: International Co-operative Publishing House; 1979: 23-48.

[38] Swindel BF, Lloyd R, Patil GP, Taillie C, Conde L. U.S. National Forest Management Act, forest ecosystems diversity and diversity profiles. Conenoses. 1987;2(1):1-8. 
[39] Ten Brink BJE, Hosper SH, Colijn F. A quantitative method for description and assessment of ecosystems: the AMOEBA - approach. Marine Pollut Bull. 1991;23:265-270. DOI: 10.1016/0025-326X(91)90685-L.

[40] Lane WEM, Peters JS. Ecological objectives for management purposes: applying the amoeba approach. J Aquatic Ecos Health. 1993;2:277-286.

[41] Wefering FM, Danielson LE, White NM. Using the AMOEBA approach to measure progress toward ecosystem sustainability within a shellfish restoration project in North Carolina. Ecol Modelling. 2000;130(1-3):157-166. DOI: 10.1016/S0304-3800(00)00205-2.

[42] Collie JS, Gislason H, Vinther M. Using AMOEBAs to display multispecies, multifleet fisheries advice. ICES J Marine Sci. 2003;60(4):709-720. DOI: 10.1016/S1054-3139(03)00042-0.

[43] Chao A, Gotelli NJ, Hsieh TC, Sander EL, Ma KH, Colwell RK, et al. Rarefaction and extrapolation with Hill numbers: a framework for sampling and estimation in species diversity studies. Ecol Monographs 2014;84(1):45-67. DOI: 10.1890/13-0133.1.

\title{
METODY POMIARU I WIZUALIZACJI ZMIAN BIORÓŻNORODNOŚCI
}

\author{
${ }^{1}$ Wydział Inżynierii Środowiska, Politechnika Lubelska \\ ${ }^{2}$ Wydział Inżynierii Budowlanej, Czeski Uniwersytet Techniczny w Pradze
}

\begin{abstract}
Abstrakt: W artykule przedstawiono metody określenia biologicznych i statystycznie istotnych różnic między taksocenozami porównywanymi pod względem bioróżnorodności. W celu pełnego opisu różnic biologicznych pomiędzy porównywanymi, hipotetycznymi zbiorowiskami obliczono wskaźniki: $S$ (bogactwo taksonów), $H^{\prime}$ (indeks Shannona), $H_{\max }$ (maksymalna wartość indeksu Shannona dla danego bogactwa taksonów charakteryzujących się takimi samymi liczebnościami), $V_{d}$ (wyrażona w procentach wartość wypełnienia strukturalnych możliwości zbiorowiska; niedostatek ,równomierności”), $E$ (indeks MacArthura, czyli liczba taksonów $S$ w zbiorowisku, dla którego dany indeks $H$ przyjąłby wartość maksymalną) oraz $P_{s}$ (wyrażony w procentach niedostatek bogactwa taksonów). Dodatkowo, dla porównania bioróżnorodności zbiorowisk użyto graficznej metody profili $\Delta_{\beta}, T_{j}$ i $L_{j}$. W celu uzyskania informacji o statystycznie istotnych różnicach między analizowanymi zbiorowiskami pod względem bioróżnorodności wykreślono krzywe rarefakcji, bazujące na modelach numerycznych i metodzie Monte Carlo. Metoda rarefakcji umożliwiła określenie statystycznie istotnych różnic między wartościami bogactwa taksonów i indeksu Shannona obliczonych dla porównywanych zbiorowisk. Metoda profili oraz indeksy $V_{d}$ i $P_{s}$ pozwalają wnioskować o istotności różnic biologicznych nawet wtedy, kiedy wartości indeksów $H^{\prime}$ Shannona są do siebie liczbowo zbliżone.
\end{abstract}

Słowa kluczowe: bioróżnorodność, indeks Shannona, krzywe rarefakcji, metoda profili 